\title{
Pelatihan komputer akuntansi bagi guru-guru SMK
}

\author{
Hajrah Hamzah ${ }^{1}$, Sahade ${ }^{2}$ \\ ${ }^{1,2}$ Fakultas Ekonomi, Universitas Negeri Makassar
}

\begin{abstract}
The Community Partnership Program(PKM) program is Ba rru State Vocational School Teachers. The problem is: (1) the lack of knowledge about the field of accounting science that requires technology, (2) la ck of skills to make an application-based accounting cycle (computer accounting) and, (3) the teachers in Barru Voca tional High Schools in their activation a re still complex and havenot been revised into the actual a cc ounting records. The external target is the process of recording and in putting a ccounting data (accounting cycles) base d on the application's financial sta tements. The method used is: lectures, demonstrations, disc ussions, questions and answers, and counterpart partners. The agreed results a re (1) partners who have knowledge in the field of accounting knowledge that supports technology, (2) partners who have the skills to crea te application-based accounting cy cle s and, (3) partners who have the ability to increase knowledge, create, create, financial, efficient and effective
\end{abstract}

Key words: accounting computer, teachers

\section{PENDAHULUAN}

Pendidikan tidak dapat terlepas dari kehidupan manusia, pendidikan akan terus melekat sepanjang hidup. Pendidkan diharapkan mampu melahirkan generasi yang handal dan tangguh dalam menghadapi tantangan dan masalah yang semakin kompleks. Manusia memiliki peran baik sebagai subjek maupun objek pendidkan. Sekolah merupakan sarana pendidikan yang memfasilitasi guru dan murid untuk berinteraksi. Salah satu sistem yang ada di sekolah adalah sistem pengelolaan keuangan. Sistem ini merupakan bagian dari bidang keilmuan akuntansi.

Perkembangan ilmu akuntansi dan teknologi yang pesat memberikan dampak siginifikan dalam dunia pendidikan. Salah satu bidang keilmuan akuntansi yang dipengaruhi teknologi adalah Sistem Informasi Akuntansi (SIA). Siklus akuntansi yang secara manual sama dengan berbasis komputer. Perbedaannya terletak pada keakuratan data yang efektif dan efisien. Pencatatan akuntansi secara historis tidak cukup memberikan informasi pada era teknologi saat ini.

Perkembangan teknologi informasi berdampak signifikan terhadap SIA. Dampaknya adalah proses data dari sistema manual ke komputersasi. Sejalan dengan itu memunculkan berbagai software akuntansi yang mempermudah proses pencatatan dan pelaporan keuangan dalam suatu lembaga atau usaha.

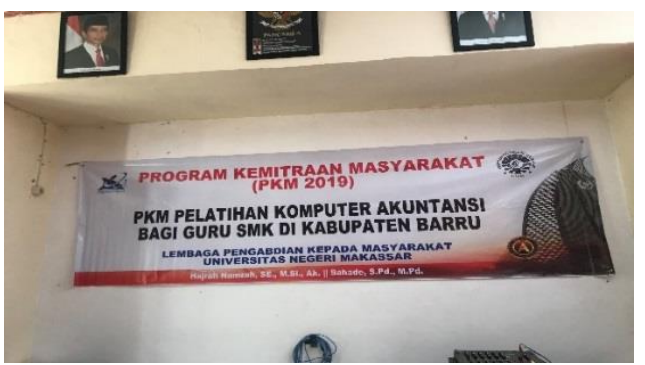

Gambar 1. Spanduk kegiatan PKM

Sehubungan dengan semakin arifnya para pelaku dalam pengambilan keputusan ekonomi serta ditunjang perkembangan teknologi informasi yang sangat pesat, maka peran akuntansi sebagai sistem informasi keuangan menjadi sangat penting dalam kehidupan perekonomian, khususnya untuk dunia usaha. Akuntansi keuangan sebagai salah satu cabang ilmu dan praktik akuntansi yang berhubungan dengan permasalahan-permasalahan pelaporan keuangan perusahaan kepada berbagai pihak pengambil keputusan diluar manajemen perusahaan (misalnya: calon kreditur dan kreditur, calon investor dan investor, Bapepam dan badan pemerintah tertentu), perlu diselenggarakan dengan berlandaskan pada standar akuntansi keuangan yang berlaku. Standar akuntansi keuangan 
merupakan pedoman yang harus diacu dalam penyusunan laporan keuangan untuk tujuan pelaporan kepada para pemakai diluar manajemen perusahaan. Agar laporan keuangan tidak menyesatkan dan tidak terjadi kesalahapahaman atas informasi yang disajikan dalam laporan keuangan, pemakai laporan keuangan perlu memahami konsep dasar, asumsi, penalaran dan keterbatasan standar akuntansi yang berlaku.

Oleh karena itu, setiap transaksi keuangan, dalam akuntansi, akan dicatat. Transaksi keuangan tersebut disebut mutasi keuangan. Nama lain dari mutasi keuangan adalah jurnal, yang harus dicatat setiap hari dalam buku jurnal harian. Akuntansi sendiri merupakan kegiatan pencatatan transaksi keuangan, mengelompokkan dan mengklasifikasikan, untuk menghasilkan laporan-laporan keuangan. Untuk memudahkan dalam pengelompokkan dan pengklasifikasian mutasi-mutasi keuangan tersebut maka dibuatlah kelompok-kelompok rekening, disebut akun, atau nomor perkiraan. Setiap transaksi yang terjadi akan menyebut akun tersebut sebagai penanggungjawabnya.

Informasi yang diberikan oleh akuntansi keuangan pada pembuatan keputusan diluar perusahaan biasanya berbentuk laporan ringkas yang dinamakan laporan keuangan, yang elemenelemennya menurut Prinsip Akuntansi Indonesia tahun 1984 terdiri dari Neraca, Ikhtisar Rugi/Laba, Laporan Laba ditahan, Laporan Arus Kas, Catatan atas laporan keuangan serta opini Auditor Independen. Informasi dalam laporan keuangan biasanya disajikan dalam bentuk yang sama dari tahun ke tahun. Informasi akuntansi keuangan biasanya ditujukan bagi kebutuhan umum seperti kepada pihak perusahaan, kreditor perusahaan, badan pemerintah, karyawan, dan serikat buruh, serta kepada para pelanggan perusahaan.

Bagi organisasi/perusahaan, informasi merupakan sumber daya yang sangat penting. Informasi diperlukan oleh pihak-pihak di dalam organisasi/ perusahaan untuk menyusun perencanaan, mengawasi dan mengadakan evaluasi terhadap kerja pengurus dan karyawan. Sedangkan pihak di luar organisasi/perusahaan memerlukan informasi untuk menilai bagaimana organisasi/perusahaan tersebut memperhatikan kesejahteraannya. Dengan demikian, informasi yang disajikan harus akurat dan relevan dengan kepentingan berbagai pihak.

Untuk dapat menjaring berbagai data yang diperlukan untuk diolah menjadi informasi, perusahaan memerlukan suatu sistem yang disebut dengan sistem informasi. Salah satu sistem informasi yang banyak diperlukan adalah sistem informasi akuntansi. Sistem informasi akuntansi disusun untuk mengumpulkan data akuntansi dan mengolahnya menjadi informasi akuntansi. Data dapat diolah menjadi informasi dengan cara manual maupun dengan bantuan komputer. Akan tetapi perkembangan bisnis yang sangat pesat memerlukan pengolahan data yang cepat, tepat waktu dan akurat.

Kenyataan di lapangan menunjukkan bahwa selama ini pihak sekolah, khususnya guru-guru di SMKN Barru dalam melaksanakan fungsinya mereka masih melakukan pencatatan yang masih bersifat sederhana dan belum mencerminkan ke dalam pencatatan akuntansi yang sebenarnya. Sebab dalam melakukan pencatatan tidak memahami prosesnya (siklusnya) akan tetapi hanya hasil akhir dari transaksi usahanya. Pada dasarnya mereka belum bisa memberikan gambaran laporan keuangan yang jelas.

Berdasarkan analisis situasi inilah, maka kami berusaha untuk memberikan pelatihan berupa keterampilan dalam pelatihankomputer akuntansi bagi guru-guru SMKN Barru.

\section{METODE PELAKSANAAN}

Perguruan tinggi berperan aktif dalam mengembangkan bidang keahlian dari para pakar dan ahli di bidang pendidikan masing-masing dalam memajukan pengetahuan dan keahlian masyarakat. Seperti yang dilakukan Universitas Negeri Makassar. Hajrah Hamzah, SE, M.Si, Ak. sebagai dosen Program Studi S1 Akuntansi dan Sahade, S.Pd.,M.Pd sebagai dosen di Program Studi Pendidikan Akuntansi Fakultas Ekonomi Universitas Negeri Makassar diharapkan menyelenggarakan kegiatan peningkatan sistem pengelolaan laporan keuangan di SMK Negeri 
Barru. Diharapkan para peserta dapat mengambil manfaat selama proses pelatihan. Kedepannya mereka dapat mengaplikasikan hasil pelatihan ini dan mampu mensosialisaikan kepada masyarakat lainnya.

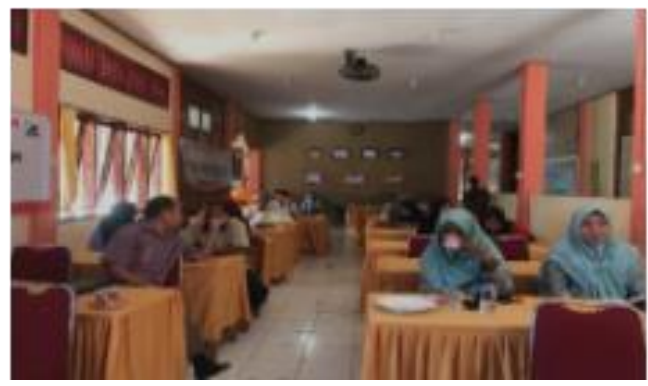

Gambar 2. Kegiatan pelatihan

Dalam kegiatan pengabdian kepada masyarakat ini digunakan metode ceramah, tanya jawab, latihan, dan diskusi. Kegiatan pelatihan ini difokuskan pada penyusunan laporan keuangan kepada guru-guru SMK Negeri Barru. Proses pelaksanaan kegiatan pengabdian kepada masyarakat ini dilakukan melalui pelatihan komputer akuntansi bagi guru-guru SMKN Barrudimulai dari tahap persiapan, pelaksanaan dan evaluasi.

\section{PELAKSANAAN DAN HASIL KEGIATAN}

Khalayak sasaran umum kegiatan pengabdian bagi masyarakat ini adalah guru-gurui SMK Negeri Barru. Namun yang menjadi sasaran khusus adalah guru-guru SMKN 1 dan SMKN 2 dengan peserta pelatihan sebanyak 15 orang.

Dari 15 orang guru-guru SMKN 1 dan SMKN 2 Barru diharapkan dari hasil kegiatan pelatihan minimal 8 orang peserta pelatihan yang sudah memiliki pengetahuan dan keterampilan yang sangat baik, sehingga 8 orang ini dapat menyebar luaskan pengetahuan dan keterampilan mereka dalam menyusun laporan keuangan berbasis aplikasi sehingga ke depan guru-guru SMKN Barru dapat membagi pengetahuan mereka kepada para siswanya.
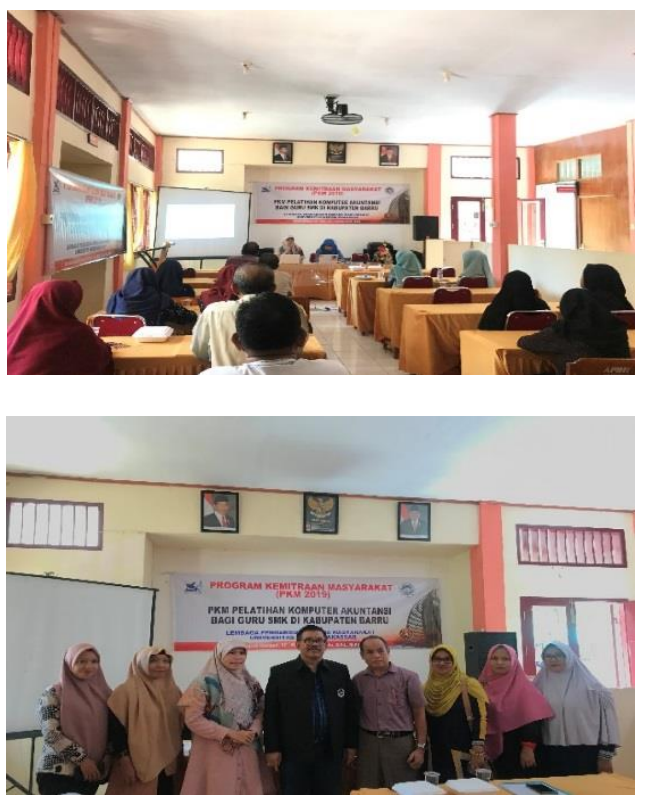

Gambar 3. Kegiatan PKM

Materi pelatihan pada kegiatan pengabdian kepada masyarakat yang dilaksanakan di SMK Negeri Barru berfokus pada dasar-dasar akuntansi dan penyusunan laporan keuangan, tujuan laporan keuangan, karakteristik laporan keuangan

\section{A. Laporan Keuangan}

Laporan keuangan adalah laporan yang memuat informasi yang terkait dengan keuangan perusahaan yang berguna bagi pihak yang membutuhkan yaitu pihak internal dan eksternal perusahaan. Laporan keuangan menggambarkan pos-pos keuangan perusahaan yang diperoleh dalam suatu periode (Kasmir, 2014).

\section{B. Tujuan Laporan Keuangan}

Menurut Pernyataan Standar Akuntansi Keuangan (SAK) tahun 2017, tujuan laporan keuangan adalah memberikan informasitentang posisi keuangan, kinerja serta arus kas yang bermanfaat bagi sebagian besar penggunalaporan yang berguna untuk membuat keputusan ekonomi.

\section{Karakteristik Kualitatif Laporan Keuangan}

Agar informasi dalam laporan keuangan bermanfaat bagi penggunanya, maka informasi yang disajikan dalam laporan keuangan harus memenuhi karakteristik kualitatif (Astuti, 2012). 
Karakteristik kualitatif pokok yaitu:

1. Dapat dipahami (understandability)

2. Relevan (relevance)

3. Materialitas (materiality)

4. Andal (reability)

5. Penyajianwajar

6. Substansimengunggulibentuk

7. Netralitas

8. Pertimbangansehat

9. Kelengkapan

10.Dapat dibandingkan

\section{Pendebitan dan Pengkreditan Akun}

Debit dan kredit merupakan alat akuntansi yang digunakan untuk menggambarkan perubahan dalam akun tertentu yang diakibatkan terjadinya suatu transaksi. Aturan pendebitan dan pengkreditan suatu akun terlihat pada Gambar 4.

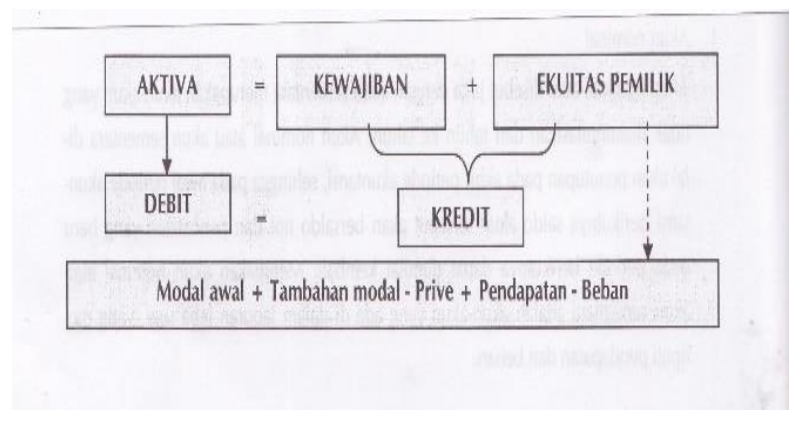

Gambar 4. Aturan pendebitan dan pengkreditan

\section{E. Siklus Akuntansi}

Siklus akuntansi dapat dilakukan secara manual maupun dengan menggunakan komputerisasi (software/aplikasia kuntansi) yang canggih. Siklus akuntansi adalah proses penyusunan suatu laporan keuangan yang dapat dipertanggung jawabkan dan diterima. Adapun tahapan dalam siklus akuntansi terlihat pada Gambar 5.

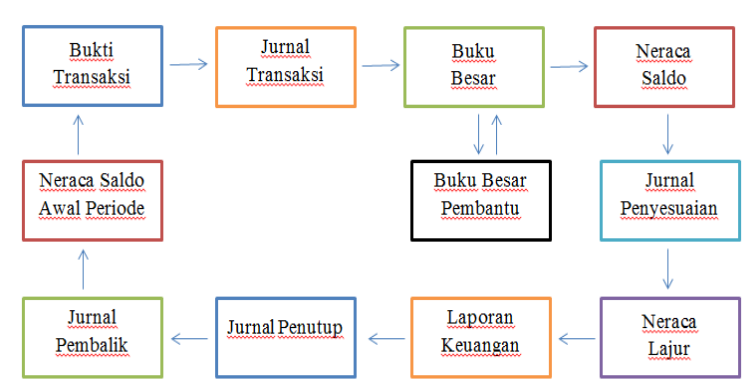

Gambar 5. Siklus akuntansi

Standar Akuntansi Keuangan memuat contoh laporan keuangan yang dapat diadopsi sesuai dengan keperluan, yaitu sebagai berikut.

\section{Neraca}

Laporan ini menyajikan posisi keuangan (aktiva dan passive) dan dapat berbentuk skontro (bentuk T-account) maupun staple (report-form). Pada bagian aktiva, disajikan urutan asset berdasarkan tingkat likuiditasnya dan di bagian passiva disajikan urutan kewajiban/utang berdasarkan jangka waktunya dan modal pemilik. Adapun contoh neraca sebagai berikut.

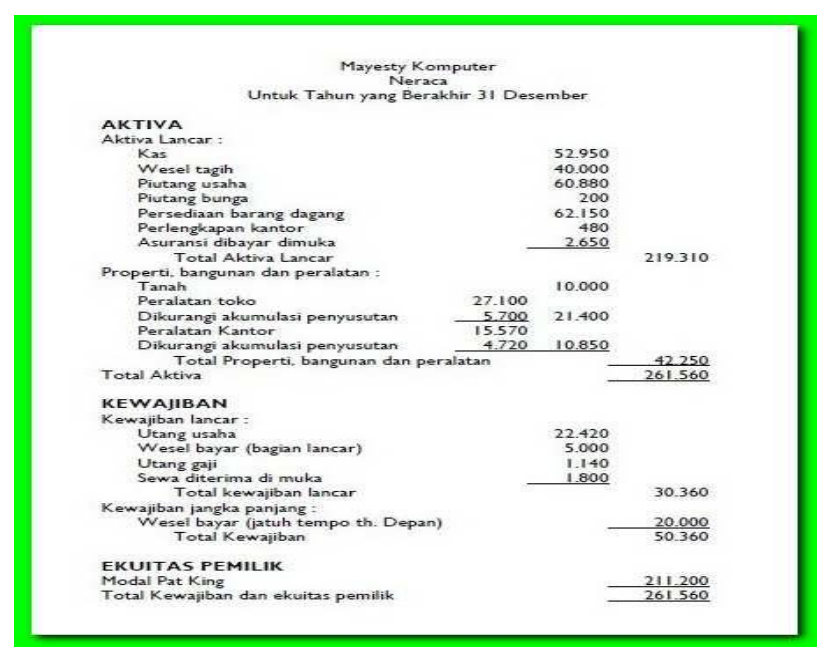

Gambar 6. Laporan neraca 


\section{Laporan laba rugi}

Di dalam laporan ini terdapat informasi ringk as mengenai jumlah biaya-biaya yang dikeluarkan untuk operasional suatu perusahaan serta laba yang didapatkan selama perusahaan tersebut beroperasi. Laporan labarugi (income statement) suatu entitas bisnis sangat diperlukan untuk mengetahui kondisi dan perkembangan perusahan, apakah memperoleh laba selama menjalankan usaha atau justru merugi.

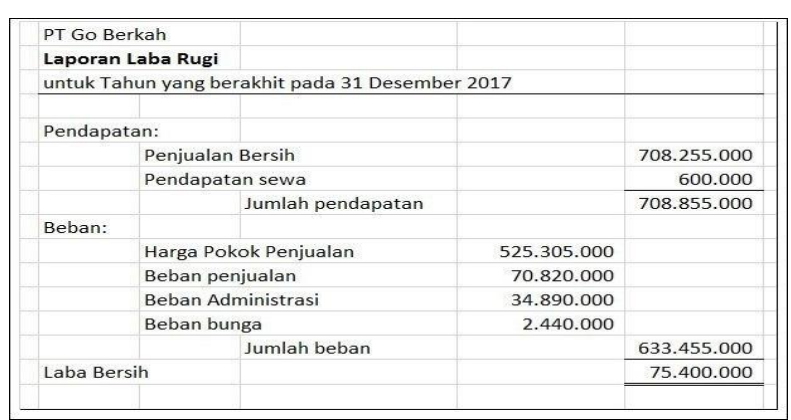

Gambar 7. Laporan laba rugi

\section{Laporan perubahan ekuitas}

Dalam banyak situasi, bisnis menyiapkan laporan keuangan "mini" yang biasadisebut laporan perubahan modal. Laporan perubahan modal atau ekuitas secara sederhana diartikan sebagai laporank euangan yang harus dibuat oleh perusahaan yang menggambarkan peningkatan atau penurunan aktivabersih atau kekayaan selama periode yang bersangkutan berdasarkan prinsip pengukuran tertentu yang dianut.

\section{PT Gama Printing \\ Laporan Peerubahan Moda \\ Untuk Periode yang Berakhir 31 Desember 2018}

Modal

Laba bersih setelah pajak

Prive

Modal akhir
Rp 240.000.000,00

Rp $14.150 .000,00$ Rp 254.150.000,00 (Rp 20.000.000.00) Rp 234.150.000,00
Gambar 8. Laporan perubahan modal

\section{Laporan arus kas (cash-flow statement)}

Laporan ini menyajikan penerimaan maupun pengeluaran kas yang bersumber dari 3 jenis aktivitas, yakni:
a. Aktivitas operasi
b. Aktivitas investasi
c. Aktivitas pendanaan

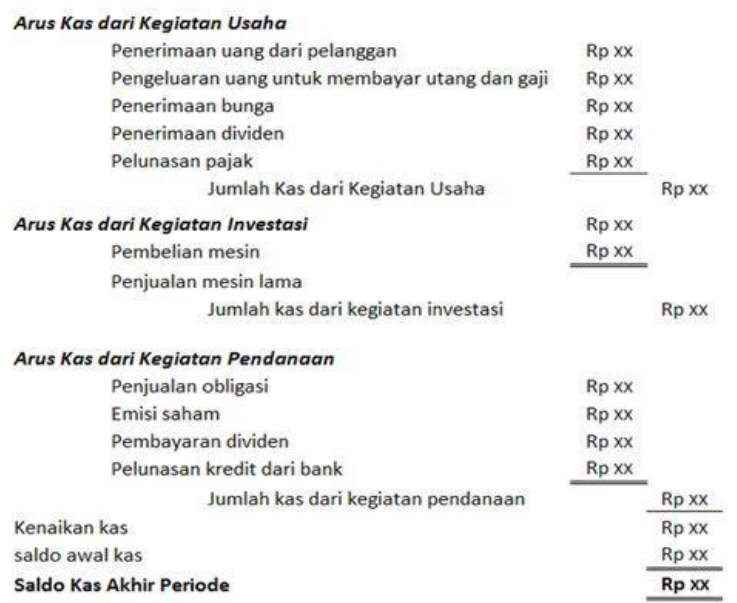

Gambar 9. Laporan arus kas

Format laporan keuangan tersebut digunakan sesuai dengan kebutuhan, dimana jumlah pengelompokan aktiva, kewajiban dan kekayaan bersih sangat tergantung pada komposisi yang ada pada perusahaan yang bersangkutan, serta jumlah pos yang akan diungkapkan disesuaikan dengan kebutuhannya (tidak harus ada semuanya).

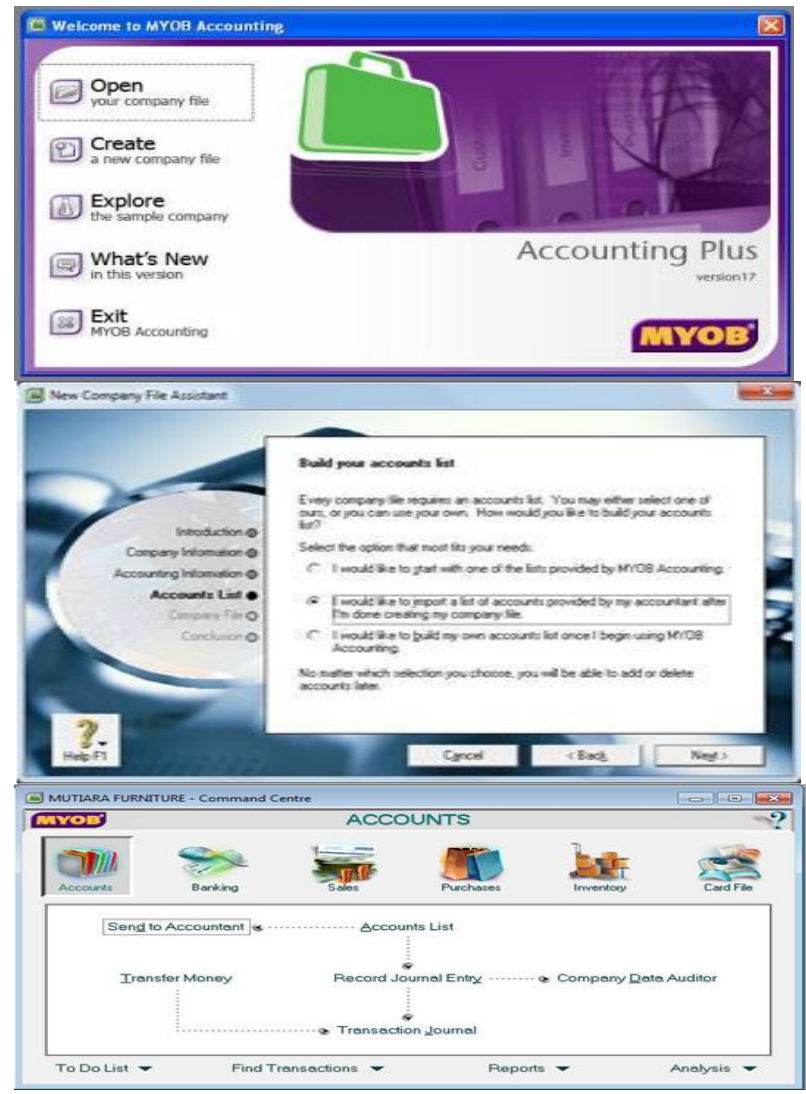

Gambar 10. Program aplikasi akuntansi 


\section{KESIMPULAN}

Perkembangan ilmu akuntansi dan teknologi yang pesat memberikan dampak siginifikan dalam dunia pendidikan. Salah satu bidang keilmuan akuntansi yang dipengaruhi teknologi adalah Sistem Informasi Akuntansi (SIA). Siklus akuntansi yang secara manual sama dengan berbasis komputer. Perbedaannya terletak pada keakuratan data yang efektif dan efisien. Pencatatan akuntansi secara historis tidak cukup memberikan informasi pada era teknologi saat ini. Dengan memberikan pelatihan penyusunan laporan keuangan kepada: para guru-guru SMKN 1 dan
SMKN 2 Barru diharapkan mereka memiliki keterampilan dan pengetahuan yang lebih baik dalam menyusun laporan keuangan berbasis komputer aplikasi.

Pengetahuan dan keterampilan yang guru-guru miliki dalam penyusuan laporan keuangan yang nantinya juga dapat menyebar luaskan guru-guru SMKN Barru.

\section{DAFTAR PUSTAKA}

Astuti, Partiwi Dwi. 2012. Akuntansi Keuangan Dasar 1. CAPS Yogyakarta.

Kasmir. 2014. Analisis Laporan Keuangan. Jakarta, Raja Grafindo Persada, Cetakan ke-7. 